\title{
Influence of Strategic Leadership on Implementation of Tactical Decisions in Public Universities in Kenya
}

\author{
Catherine K Ogaja ${ }^{1}$, George Kimiti K. ${ }^{2}$ \\ ${ }^{1}$ Egerton University, Kenya \\ ${ }^{2}$ School of Human Resource Development, Jomo Kenyatta University of Agriculture and Technology, Kenya
}

\begin{abstract}
Today many Public Universities have failed to implement well thought out strategies. Literature indicates that numerous studies acknowledge that strategies frequently fail not because of inadequate strategy formulation, but because of insufficient implementation of tactical decisions. This study was a comparative analysis of implementation of tactical decisions in Public Universities focusing on Egerton University and Jomo Kenyatta University of Agriculture and Technology. Relevant literature was reviewed guided by Rational Decision Making theory. The study employed a descriptive research design. A census was conducted and structured questionnaires administered to Chairpersons of Departments and Heads of Sections of the two universities. Data analysis was done in form of both descriptive and inferential statistics with the aid of statistical package for social sciences (SPSS) version 21. Correlation analysis was done to determine the relationship between the variables under study. The findings indicated that strategic leadership influences the implementation of tactical decisions in both institutions. The researcher concluded that strategic leadership plays an important role in the implementation of tactical decisions. The researcher recommended that Universities should review their leadership style and embrace strategic leadership to assist in making tactical decisions in the institutions.
\end{abstract}

Keywords: strategy, Strategic Leadership, Implementation, Tactical decisions, Public Universities

\section{Introduction}

Decision making is central to all the managerial activities, be it planning, organizing, staffing, directing or controlling. Decision making is a process of making choices from alternative courses of action, based upon factual and value premises with the intention of moving towards a desired state of affairs. It is the thought process of selecting a logical choice from the available options. Once a decision is taken, it implies commitment of resources. The decision that a manager has to take may range from setting of goals and targets for the entire business enterprise to specific decisions regarding day to day activities. Some of them may have only short-term implications, while others may have long-term implications on the enterprise [49]. The essence of decision making seems to integrate both the beliefs about specific events and peoples subjective reactions to those events.

Strategic decisions are major choices of actions and influence whole or a major part of business enterprise. They contribute directly to the achievement of common goals of the enterprise. They have long-term implications on the business enterprise. They may involve major departures from practices and procedures being followed earlier. Generally, strategic decisions are unstructured and thus, a manager has to apply his business judgment, evaluation and intuition into the definition of the problem. These decisions are based on partial knowledge of the environmental factors which are uncertain and dynamic. Such decisions are taken at the higher level of management [15]. Strategic decisions are long term, highly unstructured, complex and inherently risky and have great impact on the future of the organization. Strategic decisions are those important decisions that typically require a large amount of organizational resources and firm's environment consideration. In strategic decisions, top management usually plays a central role in making the decisions. These decisions influence organizational direction, administration and structure [13].

Tactical decision making allows a company to evaluate its infrastructure and how it operates and make adjustments accordingly. To make a tactical decision, a board analyzes information it is presented, and determines an immediate course of action with the intention of achieving a specific goal that will directly and immediately benefit the most people. A study [8] suggests that although tactical decisions do involve many people and departments, tactical decisions tend to have a limited impact in the case of their failure because they can be adjusted and changed relatively quickly. Tactical decisions are medium term decisions. Whereas a misguided strategy could take a business in entirely the wrong direction and lead to failure, a misguided tactic would have a more limited impact. Strategies are usually in place for a long period of time; tactics tend to be more changeable. If a tactic fails to achieve outcomes it can be adjusted or changed. Tactical decisions include choosing which employees to consult with the managers of each area, the people carrying out the job; what channels of communication to use in group discussions, one-to-one meetings and how much time to spend on each aspect. [31].

The Kenyan Government in its effort to improve service delivery to the public introduced performance based contracts for the top management where they are required to prepare strategies which are cascaded down to the junior staff. The renewal of their contracts is based on the performance management system and as such managers are given tasks with pre-determined successes. Their main role is to strategize how best these targeted results are to be 


\section{International Journal of Science and Research (IJSR) \\ ISSN (Online): 2319-7064 \\ Index Copernicus Value (2013): 6.14 | Impact Factor (2014): 5.611}

accomplished. The task of formulating strategy entails taking into account all of the relevant aspects of the organization's internal and external environment and coming up with a detailed action plan for achieving the targeted short-run and long term goals. The developing and developed countries have since the 1980s embraced reforms that focused on the management of the public sectors which resulted to the public sector being put under pressure to adopt private sector orientations [10]

Higher education in Kenya can be traced back to 1922 when Makerere University in Uganda was founded as a technical college for African students from the East African countries [36]. The college offered post-school certificate courses in fields such as teacher training and carpentry. After the publication of the Asquith Report in 1949, the Makerere University Act was passed enabling the institution to legally transform itself into the University of East Africa. It then admitted its first undergraduate students for degrees offered by the University of London in 1950. Previously, there were 7 Public Universities in Kenya with an enrolment of 100,649 students [34]. Presently the number of the Public Universities in Kenya has risen to 23. Apart from the Public Universities in Kenya, there are 29 Private Universities in Kenya.

Egerton University is the oldest institution of higher learning in Kenya. It was founded as a Farm School in 1939 by Lord Maurice Egerton of Tatton, a British national who settled in Kenya in the 1920s. In 1950, the School was upgraded to an Agricultural College offering diploma programmes. The Egerton Agricultural College Ordinance was enacted in 1955. In 1979, the Government of Kenya and the United States Agency for International Development (USAID) funded a major expansion of the institution. In 1986, Egerton Agricultural College was gazetted as a constituent college of the University of Nairobi. The following year, 1987, marked the establishment of Egerton University through an Act of Parliament.

Jomo Kenyatta University of Agriculture and Technology was started in 1981 as a Middle Level College (Jomo Kenyatta College of Agriculture and Technology (JKCAT)) by the Government of Kenya with the generous assistance from the Japanese Government. Plans for the establishment of JKCAT started in 1977. In early 1978, the founding father of the nation, Mzee Jomo Kenyatta donated two hundred hectares of farmland for the establishment of the college. The first group of students were admitted on $4^{\text {th }}$ May 1981 . H.E. Daniel Arap Moi formally opened JKCAT on $17^{\text {th }}$ March 1982. The first graduation ceremony was held in April 1984 with Diploma Certificates presented to graduates in Agricultural Engineering, Food Technology and Horticulture. On $1^{\text {st }}$ September 1988, H.E. Daniel Arap Moi, declared JKCAT a constituent College of Kenyatta University through a legal Notice, under the Kenyatta University Act (CAP 210C). The name of JKCAT officially changed to Jomo Kenyatta University College of Agriculture and Technology (JKUCAT). It was finally established as a University through the JKUAT Act, 1994 and inaugurated on $7^{\text {th }}$ December 1994.
Higher education in Kenya is experiencing changes in the form of expansion of the sector, diversification of provision, more heterogeneous student bodies, new funding arrangements, increasing focus on accountability and performance, global networking, mobility and collaboration. These changes have challenged institutional management. However, more than ever before, management need to revise and specify institutional mission statements, assess impact of new sources of funding, meet requirements for accountability, consider participation in globalization, international competition and the requirements for national, regional and international integration [28]. Numerous tactical decisions must be made in response to the needs of Public Universities. Many of these decisions are concerned with the timely and efficient procurement, allocation and distribution of resources (e.g. funds, supplies,) through a supply chain in order to ensure efficiency and effectiveness in delivery of service.

\section{Statement of the Problem}

Tactical decision making is an integral part of the strategic management process which entails implementation of strategic decisions. Public Universities in Kenya are faced with developmental problems in the process of implementing their strategic plans. There is also very high competition in the market to offer programmes that will meet the market needs. As a result of this, Public Universities face the challenge of ensuring that decisions at all levels are implemented in order to achieve the desired results. Universities today are operating under high level of uncertainty and thus implementation of tactical decisions are open to all sorts of external influence, unexpected events, ever growing requirements, changing constraints and fluctuating resource flows [49]. This clearly shows that if decisions are applied and steps are not taken in order to manage them effectively and efficiently, the chance of failure is high. It is thus timely to focus attention on the search for strategies that will improve performance of the Universities.

Top Managers play a critical role in decision making and middle managers expect direction and support from their top management. Middle Managers expect top management direction but frequently feel that they are in a better position to start and evaluate alternative courses of action. In reference to the emerging importance of decision making, the driving force in the search for an analysis of implementation of tactical decisions in public Universities in Kenya is thus paramount owing to the fact that it is vital to identify factors that contribute to the successful implementation of tactical decisions to enable the Universities deliver results as stipulated in their strategic plans. Additionally there is no evidence from studies to establish whether there is strategic fit or alignment between strategic decision making and the implementation of tactical decisions.

\section{Objective of the Study}

The study aimed at establishing the influence of strategic leadership on the implementation of tactical decisions in Public Universities in Kenya. 


\section{International Journal of Science and Research (IJSR) \\ ISSN (Online): 2319-7064}

Index Copernicus Value (2013): 6.14 | Impact Factor (2014): 5.611

\section{Research Question}

How does strategic leadership influence implementation of tactical decisions in Public Universities in Kenya?

\section{Conceptual Framework}

The researcher conceptualized a framework consisting of the dependent and independent variables. This was aimed at guiding the researcher in achievement of the research objective (establishing the effect of strategic leadership on tactical decision implementation).

\section{Strategic
Leadership $\longrightarrow$\begin{tabular}{c}
$\begin{array}{c}\text { Tactical decision } \\
\text { implementation }\end{array}$ \\
\hline
\end{tabular} \\ Independent variable Dependent variable}

Figure 1: Conceptual framework

\section{Literature Review}

The review will involve studies previously done on strategic leadership and tactical decision implementation, globally; regional and finally in Kenya.

\subsection{Theoretical Review}

The study draws from the theory of rational decision making. Decision making is the thorough process of selecting a logical choice from the available options. When trying to make a good decision, a person must weigh the positives and negatives of each option and consider all available alternatives. This is because decision making errors are costly and are growing more costly [2]

\subsubsection{Rational Decision Making Theory}

A rational decision making theory provides a structured and sequenced approach to decision making. Rational decision making is a method for systematically selecting among possible choices that is based on reason and facts. In a rational decision making process, a business manager will often employ a series of analytical steps to review relevant facts, observations and possible outcomes before choosing a particular course of action. Rational decision making is a multi-step process, from problem identification through solution, for making logically sound decisions [17]. A study to establish the relationship between individual and collective rationality found that rational managers will decide in favor of organizations and institutions that serve their respective individual interests, with competition among individuals also evident in this process [3].

It is believed by some philosophers notably [16] that a good rationale must be independent of emotions, personal feelings or any kind of instincts. Any process of evaluation or analysis, that may be called rational, is expected to be highly objective, logical and mechanical. If these minimum requirements are not satisfied that is if a person has been, even slightly, influenced by personal emotions, feelings, instincts or culturally specific, moral codes and norms, then the analysis may be termed irrational, due to the injection of subjective bias. Rational decision making models involve a cognitive process where each step follows in a logical order from the one before. Cognitive, means it is based on thinking through and weighing up the alternatives to come up with the best potential result [48].

\subsection{Empirical Review}

The decision-making phenomenon has been a frequently studied topic by several areas of human knowledge. According to research findings, [20] although more than three decades of systematic research on decision science have provided insights on a variety of issues, many areas of the decision making field still need to be uncovered. This section provided an empirical review of studies done on strategic leadership, decision support system and internal management environment and their influence on the implementation of tactical decisions in organizations. Finally the researcher provided empirical review of studies on tactical decisions and their implementation.

\subsubsection{Implementation of Tactical Decisions}

Tactical decision making is an integral part of strategic decision making process as it involves converting strategic decisions into action. Strategic decisions are those that are important in terms of actions taken, the resources committed or the precedents set [33]. They are infrequent decisions made by the top leaders of an organization that critically affect organizational health and survival [41].

Furthermore, the process of creating, evaluating and implementing strategic decisions is typically characterized by the consideration of high levels of uncertainty, potential synergies between different options, long term consequences and the need of key stakeholders to engage in significant psychological and social negotiation about the strategic decision under consideration. For effective decision making, a person must be able to forecast the outcome of each option as well and based on all these items determine which option is the best for that particular situation. Strategic decisionmaking is the process of developing and putting into action choices that will influence the long-term welfare of the organization.

These choices often involve major organizational changes and large resource commitments that are difficult to reverse once they are implemented. Strategic decision-making reflects decision makers' experience, the positions they occupy and their organizational environment. Work on improving strategic decision-making has focused on the content of decision outcomes and the process that produces these outcomes. Strategic decision-making takes place within a context defined by the organization's strategy and varies according to the extent to which this strategy is a deliberate, as opposed to an emergent, process [12].

Tactical decision making focuses on the big picture and the here and now. When making tactical decisions, the organization as a whole is involved. Tactical decision making allows an organization to evaluate its infrastructure and how it operates and make adjustments accordingly. To make a tactical decision, a board analyzes information it is presented, and determines an immediate course of action with the intention of achieving a specific goal that will 


\section{International Journal of Science and Research (IJSR) \\ ISSN (Online): 2319-7064}

Index Copernicus Value (2013): 6.14 | Impact Factor (2014): 5.611

directly and immediately benefit the most people. Many organizations know their business and the strategies required for success.

However many corporations including public corporations struggle to translate strategic decisions into action plans that will enable these decisions to be successfully implemented and sustained. According to reseach [5] most companies have strategies but far fewer achieve them. Organizations fail to do so not because of bad strategic decision making process but because of bad execution, therefore effective decision making is important in achieving successful decision making.

Research have established that a company's strategy consists of competitive moves and approaches management has developed to attract and please customers, conduct operations, grow the business and achieve performance objectives[13]. Strategic decisions are ill structured, nonroutine and important to the firm in which top management usually plays a central role. Strategic decision making is incremental and interdependent, shaped by a variety of contextual influences arising from past events, present circumstances and perspectives of the future. One of the central features of strategic decisions is their lack of structure mainly due to the complexity of the strategic problems [37].

Tactical decisions relate to the implementation of strategic decisions. They are directed towards developing divisional plans, structuring workflow, establishing distribution channels, acquisition of resources such as men, materials and money. These decisions are at the middle level management. Tactical decision making is a business strategy where decisions are made with the end result of ensuring a company is as successful as possible. This means the company makes decisions that will contribute to the longevity, profitability, and continued improvement of all areas of operation. Tactical decision making focuses on the big picture and the here and now. When making tactical decisions, the company as a whole is involved [38].

Tactical decision making takes a company's strategic decisions and sets forth specific short-term actions and plans, usually by company department or function. The tactical decisions horizon is shorter than the strategic decision horizon. If the strategic decision is for five years, tactical decisions might be for a period of one to three years, or even less, depending on what kind of market the business serves and the pace of change. These decisions represent the management's commitment to pursue particular actions in growing the business, attracting and pleasing customers, competing successfully, conducting operations and improving company's financial and market performance [50].

According to a study [33] implementation of tactical decisions is an important component of an organization and is defined as the process that turns strategic decisions to accomplish organizational objectives and its success is vital for any organization. Tactical decision making addresses the here and now activities of an organization that are key to achieving competitive advantage for an organization. The major source of decision complexity is the inter-relationship among choices. The challenge for managers is thus to devote a substantial amount of time working to achieve a holistic and satisfactory focus on their implementation process.

Research underlines the tactical decision maker's attitudes towards different factors influencing the quality of business decisions; these factors include information sources, analytical tools, and the role of information technologies [47]. Further attention is paid to the impact of information availability on manager's ability to process and use information in short and long term planning and in tactical decision making tasks. He revealed that the better the availability of information, the better the impact on both efficiency and accuracy of implementation of tactical decisions [19]. Tactical level decisions are those that come up in response or reaction to some issue within an existing organization. Both strategic and tactical decisions are important for the achievement of strategic objectives of any organization. Tactical decisions get less scrutiny compared to strategic decisions.

The formulation of strategic decisions has been widely regarded as the most important component in strategic management, more important than the implementation of tactical decision making. However, research indicates that the ability to implement tactical decisions is viewed as considerably more important than the formulation of strategic decisions and that the implementation of tactical decisions and not the formulation of strategic decisions is the key to superior performance and achieving of competitive advantage for organizations [21].

According to research [26], effective implementation of tactical decisions is more important than the content of strategic decisions. They established that firms that focus their attention on having their tactical decisions effectively implemented realize a higher percentage of improved quality in their products and services and their shareholder value. However a similar improvement in the suitability of the strategic decisions had no effect on organizational performance.

The challenges arise particularly when decision makers are engaged with complex issues involving multiple stakeholders, unanticipated events, ad hoc structures or groups, and uncertain or unstable environments [43]. In situations involving complex issues that require rapid decision making, achieving the right mix of control and creative freedom is critical for sustainable success. These types of decisions often present high stakes and involve ad hoc groups made up of individuals who may not know each other, but who find themselves with the shared need for quick decisions and mobilization of resources. These groups are characterized by distributed information, resources, and participants and emerge in an unplanned or perhaps even unanticipated manner. Too much control paralyzes action; too much freedom diffuses effort and effectiveness. Understanding how to exercise just the right level of control and optimize creative freedom under these conditions is a core function that will distinguish successful and sustainable organizations in the next several decades [43]. 


\section{International Journal of Science and Research (IJSR) \\ ISSN (Online): 2319-7064}

Index Copernicus Value (2013): 6.14 | Impact Factor (2014): 5.611

A tactical or managerial control decision will affect how the organization works for a limited period. These decisions take place within the context of the previous strategic decisions. Middle management is normally involved in tactical decisions [29]. Tactical decisions concern activities that have a longer time-span than operational activities. They are primarily concerned with the most appropriate effective use of the resources already available in the company [11].

One of the ways in which the management team should ensure that they successfully execute tactical decisions is through having the required skills. A Skill is a person's ability to implement specific procedures to move others to perform the task that needs to be accomplished effectively and efficiently. Acquisition of skills leads to development of goals that guide everyone in the organization to improve performance and achieve the set goals. A well skilled manager also establishes the context through which stakeholders such as employees can perform at peak efficiency. Implementation of tactical decisions is about how skilled the manager is, how efficient the systems to facilitate his operations in the firm are and how enabling the environment in which he works is in order to create competitive advantage [26].

Given that emphasis on access to education is one of the problems which over half of Public and Private Universities experience and had led to inadequate attention being paid to quality it is thus necessary that more attention should be given to the implementation of tactical decisions in order to achieve quality education [51]. A major report [42] emphasized that the Ministry of Education needed to give more priority to research in the advancement of education for it was evident that this area had not been richly developed in Kenya by ensuring decisions are implemented.

\subsubsection{Influence of Strategic Leadership on Implementation of Tactical Decisions}

Leadership is presumed to have an effect not just on individuals but also on teams, and sometimes even on entire organizations [23]. Leadership enables followers to be motivated and perform, but also small teams to synergize and organizations to accomplish goals through the differentiated yet synchronized efforts of these individuals and teams [7]. As such, leadership is an inherently multilevel phenomenon $[6 ; 52]$. Organizational effectiveness hinges on coordinated leadership being enacted from leaders residing within multiple hierarchical levels, whose leadership shapes crucial individual, team, and organizational level outcomes. Despite this reality, research on leadership often seems disconnected [54] owing at least in part to separate disciplinary groups which guide theory and research on leadership at different levels; for example, organizational level leadership research is generally the province of business scholars, whereas lower level managerial leadership research has a strong grounding in psychology [7].

Leadership of organizations, defined as dealing with strategy, along with the indirect impact on those deep within the organization, is a very recent topic of study. The latter is termed as strategic leadership while the former is referred to as supervisory leadership [3]. The diverse priorities of the two leadership functions emerge as follows: strategic leadership focuses on the survival and success of the organization, its critical audience involves the community of employees, and its time horizon is long term. Supervisory leadership focuses on the accomplishment of tasks, its critical audience involves individuals, and its time horizon is medium to short-term [25]. Strategic and supervisory leadership differ in level of analysis of the outcome variables, strategic leadership is frequently linked to archival sources of tangible organizational performance [24], whereas supervisor approaches to leadership are linked to perceptual variables (subordinate' job satisfaction and subordinate performance) [22].

In the contemporary wave organizations face different kinds of challenges than during previous waves and as a result the requirements for leadership are different $[1 ; 44]$. In the industrial economy, the challenge was inside the firm (internal) that is coordinating the physical assets produced by employees. In other words, during the Industrial Wave those organizations that could optimize their physical production well were considered successful [4; 44]. In the $21^{\text {st }}$ century, the landscape turned very competitive, due to trends of globalization, democratization and technology [18], putting strain on the very boundaries and structures of organizations. The external environment drew more and more attention.

The Center for Creative Leadership's (CCL) study [30], titled the changing nature of leadership found that the challenges facing leaders today are becoming more complex and difficult to solve that collective leadership has become a necessity. Their study surveyed more than 350 middle to top-level managers across the world to explore the current and future state of leadership. $84 \%$ of the surveyed participants believed that the definition of effective leadership had changed in the five years preceding the study. And more than $60 \%$ agreed that leaders face challenges beyond their individual capabilities. The Center for Creative Leadership suggests that in order to meet the complex challenges being faced by organizations today and into the near future, connected leadership, [30] is increasingly important.

A more collective approach to leadership is not only warranted given the pressures from outside the organization; internal pressures push in the same direction. A more highly educated workforce has greater knowledge to offer to the organization. Throughout history, leadership has been seen as the prerogative and duty of the privileged and minority elite. For the lion's share of human evolution, the vast majority was uneducated and explicably disenfranchised. Power and control were vested and remained in the privileged, who, in the best of times, ruled mercifully, if paternalistically. With widespread education and a swelling middle-class, such governance becomes untenable. Today's employees desire more from work than just a paycheck. They want to make a meaningful contribution [27], which is increasingly achieved through team-based knowledge work [32]. With the shift towards team-based knowledge work, the traditional models and approaches to leadership have become less appropriate. While one typically thinks of 


\section{International Journal of Science and Research (IJSR) \\ ISSN (Online): 2319-7064}

Index Copernicus Value (2013): 6.14 | Impact Factor (2014): 5.611

leadership as one person projecting downward influence on followers which is termed as vertical leadership, an alternative could be that all knowledge workers contribute to the leadership process which is referred to as shared leadership [40].

Even though there have been some precursor concepts for nearly a century, the leadership field only recently began to take the idea of shared leadership seriously [9]. A study [14] noted that it is interesting to reflect on why such a significant insight expressed so clearly by several authoritative voices a generation apart, has been so neglected in contemporary leadership literature. This neglect may be partly due to the above mentioned fact that throughout the $20^{\text {th }}$ century there was no need for such a concept, given that most organizations were operating within the industrial paradigm characterized by single leaders in formal positions wielding power and influence over multiple followers who had relatively little influence on top-level managers' decision making [45].

Research [53] notes that it does not require an individual who can perform all of the essential leadership functions, only a set of people who can collectively perform them. Some leadership functions such as making important decisions may be shared by several members of a group, some leadership functions may be allocated to individual members, and a particular leadership function may be performed by different people at different times. The leadership actions of any individual leader are much less important than the collective leadership provided by members of the organization. Another definition of shared leadership was that it is a dynamic, interactive influence process among individuals in groups for which the objective is to lead one another to the achievement of group or organizational goals or both. This influence process often involves peer, or lateral, influence and at other times involves upward or downward hierarchical influence [40].

\section{Methodology}

The study employed a descriptive research design [46]. Research [39] states that descriptive research design is important in carrying out both explanatory and preliminary studies as it permits researchers in collecting information, summarizing and interpreting with the view of clarifying the information. Studies [35] on the other hand give the purpose of descriptive research as determining and reporting the way things are. The target population of this study was the Chairpersons of Departments and Heads of Sections in Public Universities namely Jomo Kenyatta University of Agriculture and Technology and Egerton University since they undertake tactical decision making on a daily basis aimed at achieving the strategic decisions of their institutions.

A census was carried out since it is the procedure of systematically acquiring and recording information about the members of a given population. As such the total respondents for the study were 60 heads of departments and 22 Heads of sections from the two universities. The primary data was collected by use of questionnaires as the data collection instrument which was pre-designed and pre-tested in relation to the objectives of the study and was administered to the respondents. The questionnaires consisted of structured (closed ended) questions. The pilot study enabled the researcher check on the statistical and analytical processes to determine if they were effective. The pilot survey was administered to a section of the Chairperson of Departments and Heads of Departments but who did not participate in the survey. Cronbach alpha coefficient was established to check on the reliability of the instrument.

\subsection{Data Processing and Analysis}

Data collected was coded, keyed in the computer and analysed with the aid of the Statistical Package for Social Sciences (SPSS). Descriptive statistics (frequencies and percentages) were used to describe the findings while inferential statistics (correlation analysis and Regression analysis) was used to test the hypothesis.

\subsection{Research Findings}

The response rate for this study was $87.7 \%$ which can be characterized as very good and thus a good indicator that the results are externally valid and therefore can be generalized.

\subsubsection{Strategic Leadership}

As regards how strategic leadership influences the operations of the two institutions, the following were the findings.

Table 1: Strategic Leadership

\begin{tabular}{|l|c|c|c|c|c|c|}
\hline & & JKUAT & & & Egerton & \\
\hline & $\mathrm{N}$ & Mean & $\begin{array}{l}\text { Std. } \\
\text { Dev }\end{array}$ & $\mathrm{N}$ & Mean & $\begin{array}{c}\text { Std } \\
\text { Dev }\end{array}$ \\
\hline $\begin{array}{l}\text { Employees are motivated to } \\
\text { perform their best }\end{array}$ & 30 & 3.70 & .877 & 34 & 3.65 & .981 \\
\hline $\begin{array}{l}\text { Our organization is able to } \\
\text { accomplish its goals through } \\
\text { differentiated yet } \\
\text { synchronized efforts of } \\
\text { individuals }\end{array}$ & 30 & 4.00 & .643 & 34 & 4.03 & .577 \\
\hline $\begin{array}{l}\text { Staff empowerment has } \\
\text { enabled the institution to deal } \\
\text { with complex challenges } \\
\text { facing institutions today }\end{array}$ & 30 & 3.73 & .583 & 34 & 3.65 & .884 \\
\hline $\begin{array}{l}\text { Employees are able to make } \\
\text { meaningful contribution to } \\
\text { decisions in the institution }\end{array}$ & 30 & 4.03 & .490 & 34 & 3.62 & .922 \\
\hline $\begin{array}{l}\text { The institution doesn't } \\
\text { require an individual to } \\
\text { perform all leadership } \\
\text { functions but people to } \\
\text { collectively perform them }\end{array}$ & 30 & 1.97 & .765 & 34 & 2.47 & 1.107 \\
\hline $\begin{array}{l}\text { Individual leaders face } \\
\text { challenges beyond their } \\
\text { individual capabilities }\end{array}$ & 30 & 2.37 & .669 & 34 & 2.38 & .853 \\
\hline $\begin{array}{l}\text { Institutions leadership just } \\
\text { focuses on the } \\
\text { accomplishments of tasks and } \\
\text { its time horizon is medium to } \\
\text { short term }\end{array}$ & 30 & 2.63 & .964 & 34 & 2.21 & 1.095 \\
\hline Valid N (listwise) & 30 & & & 34 & & \\
\hline
\end{tabular}




\section{International Journal of Science and Research (IJSR) \\ ISSN (Online): 2319-7064}

Index Copernicus Value (2013): 6.14 | Impact Factor (2014): 5.611

Respondents from both the institutions showed similarities in all the aspects relating to strategic leadership. The respondents in both institutions disagreed with the assertion that the institution doesn't require an individual to perform all leadership functions but people to collectively perform them and that individual leader face challenges beyond their individual capabilities. These two aspects recorded means approximately to 2 (Disagree). There was greater agreement in responses among the respondents of JKUAT having registered standard deviations of less than 1 in all the aspects. This is contrary to the responses from Egerton University where some responses had standard deviation greater than 1 indicating diverse opinions among the respondents. Respondents in JKUAT were indifferent on whether institutions leadership just focuses on the accomplishments of tasks and its time horizon is medium to short term registering a mean of approximately 3 (Not sure). On the other hand, respondents from Egerton disagreed with this assertion with a mean of approximately 2 (Disagree).

\subsubsection{Implementation of Tactical Decisions}

The researcher went further ahead and sought to establish the status of tactical decisions implementation in both the institutions and how this have influenced operations of the institutions. The findings for the analysis are as presented in Table 4.7.

Table 2: Tactical Decisions Implementation

\begin{tabular}{|l|l|l|l|l|l|l|}
\hline & & JKUAT & & & Egerton & \\
\hline & $\mathrm{N}$ & Mean & $\begin{array}{l}\text { Std. } \\
\text { Dev }\end{array}$ & $\mathrm{N}$ & Mean & $\begin{array}{l}\text { Std. } \\
\text { Dev }\end{array}$ \\
\hline $\begin{array}{l}\text { Through tactical decisions } \\
\text { resources have been committed } \\
\text { to the right functions }\end{array}$ & 30 & 3.20 & .961 & 34 & 3.65 & 1.041 \\
\hline $\begin{array}{l}\text { Tactical decisions are based on } \\
\text { the institution strategy }\end{array}$ & 30 & 3.67 & .884 & 34 & 4.06 & .736 \\
\hline $\begin{array}{l}\text { To implement tactical decisions } \\
\text { the institution has re-evaluated } \\
\text { its infrastructure and made } \\
\text { adjustments accordingly }\end{array}$ & 30 & 1.53 & .507 & 34 & 2.53 & .563 \\
\hline $\begin{array}{l}\text { There has been little success in } \\
\text { implementing tactical decisions }\end{array}$ & 30 & 3.07 & .944 & 34 & 2.82 & .904 \\
\hline $\begin{array}{l}\text { Through implementation of } \\
\text { tactical decisions, the } \\
\text { institution has been able to } \\
\text { attract and please customers }\end{array}$ & 30 & 3.43 & .858 & 34 & 3.56 & .927 \\
\hline $\begin{array}{l}\text { Tactical decision } \\
\text { implementation has enabled the } \\
\text { institution to grow and achieve } \\
\text { performance objectives }\end{array}$ & 30 & 4.17 & .592 & 34 & 3.82 & .936 \\
\hline $\begin{array}{l}\text { Success in implementation of } \\
\text { tactical decision is as a result of } \\
\text { involvement of the institution } \\
\text { as a whole in the formulation } \\
\text { stage }\end{array}$ & 30 & 3.83 & .986 & 34 & 3.91 & .965 \\
\hline Valid N (list wise) & 30 & & & 34 & & \\
\hline
\end{tabular}

Respondents from JKUAT were not sure that through tactical decisions resources have been committed to the right functions whereas those from Egerton agreed with the statement. Respondents from JKUAT disagreed with the assertion that to implement tactical decisions the institution has reevaluated its infrastructure and made adjustments accordingly while those from Egerton were not sure about it Responses from both institutions indicated high levels of agreement with almost all of them registering standard deviations less than 1 .

\subsubsection{Influence of Strategic Leadership on Tactical Decision Implementation}

The researcher in this case analyzed the data collected with the view of establishing the underlying relationships between the independent variable and the dependent variable. The analysis enabled the researcher to draw pertinent inferences or conclusions regarding strategic leadership influence on the implementation of tactical decisions within JKUAT and Egerton University. All the responses were on a likert scale and thus could viably be consolidated into a composite score of their means in order to infer in their relationships. The analysis was carried out by the use of Pearson Correlation Coefficient. The findings of the analysis were as presented in Table 4.8.

Table 3: Strategic Leadership and Tactical Decision Implementation

\begin{tabular}{|c|c|c|c|}
\hline & & & $\begin{array}{c}\text { Strategic } \\
\text { Leadership }\end{array}$ \\
\hline & \multirow{3}{*}{$\begin{array}{l}\text { Tactical Decision } \\
\text { Implementation }\end{array}$} & Pearson Correlation & $.533^{* *}$ \\
\hline \multirow[t]{3}{*}{ JKUAT } & & Sig. (2-tailed) & .002 \\
\hline & & $\mathrm{N}$ & 30 \\
\hline & $\begin{array}{l}\text { Tactical Decision } \\
\text { Implementation }\end{array}$ & Pearson Correlation & $.487^{* *}$ \\
\hline \multirow[t]{2}{*}{ Egerton } & & Sig. (2-tailed) & .003 \\
\hline & & $\mathrm{N}$ & 34 \\
\hline
\end{tabular}

**. Correlation is significant at the 0.01 level (2-tailed).

The findings of the analysis of results from JKUAT indicated an average positive significant relationship $(\mathrm{r}=.533, \mathrm{p}<0.01)$ between strategic leadership and tactical decision implementation. On the other hand results from Egerton University indicated that strategic leadership had a below average positive significant relationship $(r=.487$, $\mathrm{p}<0.01$ ) with the implementation of tactical decisions. As such, it was established that strategic leadership positively influences implementation of tactical decisions in both the institutions.

\section{Summary}

Descriptive statistics indicated that respondents agreed on four of the seven aspects of strategic leadership in both the institutions. The respondents disagreed that institutions don't require an individual to perform all leadership functions but people to collectively perform them and that individual leaders face challenges beyond their individual capabilities. This was in tandem with previous research [53] which noted that it does not require an individual who can perform all of the essential leadership functions, only a set of people who can collectively perform them. JKUAT respondents were in greater agreement as their responses recorded standard deviations of less than 1 as compared to responses from Egerton where some responses had standard deviation greater than 1. Inferential statistics indicated an averagely positive significant correlation between strategic leadership 


\section{International Journal of Science and Research (IJSR) \\ ISSN (Online): 2319-7064}

Index Copernicus Value (2013): 6.14 | Impact Factor (2014): 5.611

and tactical decision implementation at $1 \%$ level of significance.

\section{Conclusion}

The findings indicated that strategic leadership influences the implementation of tactical decisions in both the institutions. Therefore the researcher concluded that successful tactical decision implementation would be achieved if strategic leadership is enhanced in the institutions. Strategic Leadership enables followers to be motivated and perform, but also small teams to synergize and organizations to accomplish goals through the differentiated yet synchronized efforts of these individuals and teams. Strategic decision making takes place within a context defined by the organization's strategy and varies according to the extent to which this strategy is a deliberate, as opposed to an emergent, process. Implementation of tactical decisions would require a focus at the whole institution through strategic leadership since when making tactical decisions, the company as a whole is involved.

\section{Recommendations}

After drawing the aforementioned conclusions, the researcher deemed it rational to put across a number of recommendations. The researcher recommended that the Universities should review their leadership style and embrace strategic leadership. Strategic leadership goes a long way in incorporating everyone in decision making thus establishing coherence in the operations of the institution. This will improve on the implementation of tactical decisions in these institutions thus improving performance of these institutions. Further, universities should incorporate strategic leadership as one of the key pillars of their operational policies to ensure that the universities operate in an efficient manner. The researcher recommended that future researchers should research intensively on the dimensions of strategic leadership and their influence on tactical decision implementation.

\section{References}

[1] Barkema, H., Baum, J., \& Mannix, E. (2002). Management challenges in a new time. Academy of Management Journal, 45(5): 916-930.

[2] Bazerman, C. (2005). The unfolding nature of group decision support: Two dimension of skill.

[3] Bedeian, A. \& Hunt, J. (2006). Academic amnesia and vestigial assumptions of our forefathers. The Leadership Quarterly, 17(2): 190-205.

[4] Boisot, M. (1998). Knowledge assets: Securing competitive assets in the information economy. Oxford, UK: Oxford University Press.

[5] Chapman, J. (2004). System failure: Why governments must learn to think differently: Demos.

[6] Dansereau, F., Alutto, J., \& Yammarino, F. (1984). Theory Testing in Organizational Behavior: The Varient Approach. Englewood Cliffs, NJ: Prentice Hall.

[7] DeChurch, L., Hiller, N., Murase, T., Doty, D., \& Salas, E. (2010). Leadership across levels: Levels of leaders and their levels of impact. The Leadership Quarterly, 21(6): 1069-1085.

[8] Dezso, A., Duane, I., \& Hoshisson R., (2012). Strategic Management: Competitiveness and globalization.

[9] Drath, W., McCauley, C., Palus, C., Van Velsor, E., O'Connor, P., \& McGuire, J. (2008). Direction, alignment, commitment: Toward a more integrative ontology of leadership. The Leadership Quarterly, 19(6): 635-653.

[10] Economic Commission of Africa. (2003). Public sector Management Reforms, Ethiopia.

[11]Finlay, C. (2000). Business Policy and Strategic Management.

[12]Forbes, D. (2007). Reconsidering the strategic implications of decision comprehensiveness. Academy of Management Review.

[13] Gamble, E. \& Thompson A. (2009). Essentials of Strategic Management, McGraw-Hill, Irwin.

[14] Gardner, J. (1990). On leadership, The Free Press, New York, NY.

[15] Goldberg, M. (2009). Consumer decision making and aging: A commentary from a public policy marketing perspective. Journal of Consumer Psychology.

[16] Grayling, A. (2011). The meaning of things. Applying Philosophy to life.

[17] Grune-Yanoff, T. (2012). Paradoxes of Rational Choice Theory. In Sabine Roeser, Rafaela Hillerbrand, Per Sandin, Martin Peterson. Handbook of Risk Theory.

[18] Halal, W. \& Taylor, K. (1999). Twenty-first century economics: perspectives of socioeconomics for a changing world. New York, NY: St Martin's Press.

[19] Handzic, M. (2001). Does More Information Lead to Better Informing?

[20]Hoch, S., Kunreuther, H. \& Gunther, R.E. (2001). Wharton on making decisions. New York: Wiley.

[21] Johnson, S. (2014). Levels of Management Decision Making.

[22] Judge, T., \& Piccolo, R. (2004). Transformational and ransactional leadership: A meta analytic test of their relative validity. Journal of Applied Psychology, 89(5), 755-768.

[23] Kaiser, R., Hogan, R., \& Craig, S. (2008). Leadership and the fate of organizations. American Psychologist, 63(2): 96-110.

[24]Kor, Y. (2006). Direct and interaction effects of top management team and board compositions on R\&D investment strategy. Strategic Management Journal, 27(11): 1081-1099.

[25]Kur, E. (1995). Developing leadership in organizations: a continuum of choices. Journal of Management Inquiry, 4(2): 198-206.

[26]Lamb, C. (2006). Reforming Pentagon Strategic Decision Making. Institute for National Strategic Studies.

[27]Lawler, J. (2005). The essence of Leadership. Existentialism and leadership Leadership.

[28] Lemaitre, M. (2009). Quality Assurance in a Changing World. INQAAHE Conference. Abu Dhabi, March 2009.

[29] Mallach, E. (1994). Understanding Decision Support Systems and Expert Systems. Burr Ridge:Irwin. 


\section{International Journal of Science and Research (IJSR) \\ ISSN (Online): 2319-7064}

Index Copernicus Value (2013): 6.14 | Impact Factor (2014): 5.611

[30] Martin, A., Willburn, P., Morrow, P., Downing, K., \& Criswell, C. (2007). The changing nature of leadership. Center for Creative Leadership.

[31] Milkaman K., Chugh, D. \& Bazerman M. (2008). How can decision making be improved.

[32] Mohrman, S., Cohen, S. \& Mohrman, A. (1995). Designing team-based organizations: New forms for knowledge work. San Francisco, CA: Jossey-Bass.

[33] Montibeller G. \& Belton, V. (2006). Casual maps and evaluation of decision options - A review, Journal of the Operational Research Society.

[34] Muchiri, K. (2010). Kenya's varsity enrolment to shoot up in shake-up. Nairobi: Daily Nation Newspaper Nation Newspaper.

[35] Mugenda, O. \& Mugenda, A. (1999). Research methods: Quantitative \& Qualitative approaches.

[36] Mwiria \& Ngethe (2007). Public \& Private Universities in Kenya: New challenges, issues \& achievements.

[37] Nooraie, M. (2008). Decision's magnitude of impact and strategic decision-making process output: the medicating impact of rationality of the decision making process. Management Decision.

[38] Nooraie, M. (2012). Factors Influencing Strategic Decision Making Processes.

[39] Orodho, J. (2002). Techniques of Writing Research Proposals and Reports in Education and Social Sciences. Nairobi: Masola Publishers.

[40] Pearce, C. \& Conger, J. (2003). Shared leadership: Reframing the hows and whys of leadership. Thousand Oaks, CA: Sage Publications.

[41] Philips, K. (2007). Strategic Decision Making. Strategic Management Journal.

[42] Republic of Kenya (1999). Totally Integrated Quality Education and Training: TIQET. Report of the Commission of Inquiry into the Education System of Kenya. Nairobi: Government Printer.

[43] Saveri, A. \& Rheingold, H. (2005). Rapid Decision Making for complex issues. Schaap, J.I. (2006). Toward strategy implementation Success: An Empirical Study of the Role of Senior-Level Leaders in the Nevada Gamming Industry. UNLV Gamming research \& Review Journal, 10, 13-37.

[44] Schneider, M. (2002). A stakeholder model of organizational leadership. Organization Science, 13(2): 209-220.

[45] Seers, A., Keller, T., \& Wilkerson, J. (2003). Can team members share leadership? Foundations in research and theory. In C. Pearce \& J. Conger (Eds.), Shared Leadership: Reframing the Hows and Whys of Leadership: 77-102. Thousand Oaks, CA: Sage Publications.

[46] Shaughnessy, J., Zechmeister, E., \& Zechmeister, J. (2006). Research methods in Psychology ( $7^{\text {th }}$ Ed.). New York: McGraw-Hill Press.

[47] Skyrius, R. (2001). Business Decision Making, Managerial Learning and Information.

[48] Spohn, W. (2002). The many facets of the Theory of Rationality; Croatian Journal of Philosophy.

[49] Stokman, F., Marcel A. \& Knoop, R. (2000). Strategic Decision Making.

[50] Thompson, A., Strickland, A., Gamble, J., \& Gao, Z. (2008). Crafting and executing strategy: The quest for competitive advantage: Concepts and cases. McGrawHill/Irwin.

[51]UNESCO (2005). EFA Global Monitoring Report. http://www.portal.unesco.org/ education/en/ev.php-url.

[52] Yammarino, F., Dionne, S., Chun, J., \& Dansereau, F. (2005). Leadership and levels of analysis: A state-of the-science review. The Leadership Quarterly, 16(6): 879-919.

[53] Yukl, G. (1999). An evaluative essay on current conceptions of effective leadership. European Journal of Work and Organizational Psychology, 8(1): 33-48.

[54]Zaccaro, S. \& Klimoski, R. (2001). The nature of organizational leadership. San Francisco, CA: JosseyBass. 